\title{
PENCEGAHAN PENYEBARAN COVID-19 MELALUI INAKTIVASI VIRUS DALAM KAJIAN KINETIKA, TERMODINAMIKA, DAN KESETIMBANGAN
}

\author{
Eris Nurhayati, Dedi Riyan Rizaldi*, \& Ziadatul Fatimah \\ University of Mataram, Natural Sciences Education Study Program, Indonesian \\ *Corresponding author: dedi0313@gmail.com
}

\section{Riwayat Artikel}

Received : 24 Oktober 2020

Revised : 08 November 2020

Accepted : 22 November 2020

Published : 28 November 2020

\begin{abstract}
Abstrak: Pandemi Corona Virus Disease 2019 (COVID-19) saat ini telah menjadi salah satu tantangan global yang melampaui batas-batas wilayah, politik, ideologis, agama, budaya, dan akademik. Tujuan dari penulisan artikel ini untuk memberikan gambaran terkait proses pencegahan penyebaran COVID-19 melalui inaktivasi virus dalam kajian kinetika, termodinamika, dan kesetimbangan kimia. Metode penulisan artikel menggunakan metode deskriptif kualitatif dengan pendekatan post-positivistik yang terdiri dari 1) menentukan topik, 2) mengumpulkan bahan sebagai referensi, 3) membuat pendahuluan, 4) menentukan metode; 5) membuat pembahasan; dan 6) menarik kesimpulan kesimpulan. Berdasarkan pembahasan diperoleh bahwa satu bentuk pencegahan penyebaran COVID-19 adalah dengan cara inaktivasi virus. Bentuk pencegahan tersebut dapat dilakukan dengan tetap memperhatikan protokol kesehatan seperti menggunakan masker, menjaga jarak, dan mencuci tangan pada air yang mengalir.
\end{abstract}

Kata kunci: Inaktivasi Virus, COVID-19, Kinetika, Termodinamika,

Kesetimbangan.

\section{PENDAHULUAN}

Pandemi Corona Virus Disease 2019 (COVID-19) saat ini telah menjadi salah satu tantangan global yang melampaui batas-batas wilayah, politik, ideologis, agama, budaya, dan akademik. Tenaga medis dan petugas kesehatan masyarakat berada di garis depan, bekerja keras untuk mengendalikan, dan mengurangi penyebaran penyakit ini (Huang, et al. 2020). Penyakit ini disebabkan oleh sebuah virus baru yang awalnya bernama novel coronavirus (2019nCov). Virus ini pertama kali ditemukan di Provinsi Wuhan, China pada Desember 2019 (WHOa, 2020). COVID-19, penyakit infeksi pernafasan yang disebabkan oleh novel coronavirus SARS-CoV-2, dengan cepat telah berkembang menjadi pandemi global hanya dalam waktu dua bulan (WHOb, 2020).

Berdasarkan data yang diambil dari [LIVE] Coronavirus Pandemic: Real Time Counter, World Map, News (Roylab State, 2020) per tanggal 12 April 2020 (Gambar 1) total kasus yang terinfeksi COVID-19 di seluruh dunia sebanyak 1.793.099 kasus, dengan 109.944 kasus kematian yang tersebar di 215 negara. Jumlah kasus terbanyak, berada di Amerika Serikat yaitu sebanyak 534.361 kasus dengan jumlah kematian sebanyak 20.651 kasus (tertinggi di dunia). Sedangkan China, yang awalnya merupakan wilayah episentrum pandemi COVID-19, saat ini berada pada peringkat 6 , posisinya semakin menurun dikarenakan diklaim tidak ada lagi penambahan kasus baru.

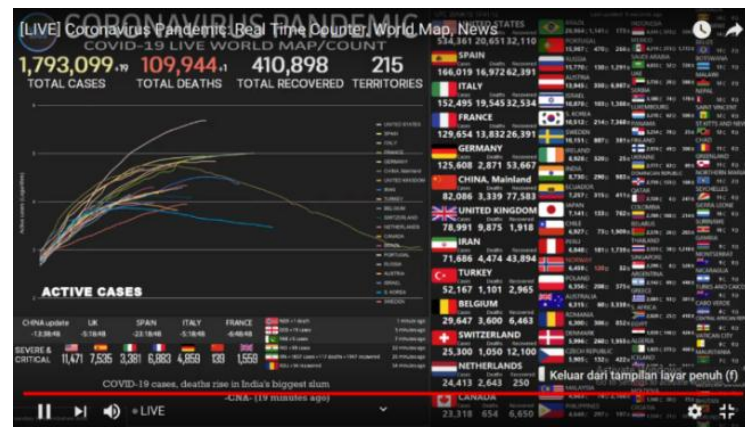

Gambar 1. Perkembangan Jumlah Kasus COVID-19 di Seluruh Dunia

(Sumber : Roylab State, 2020)

Indonesia sendiri mengkonfirmasi kasus pertama kali teridentifikasi positif menderita COVID-19 terjadi pada tanggal 1 Maret 2020. Kasus dari ibu dan anak ini terjadi karena kontak warga wilayah Depok dengan seorang warga Jepang (Kemenkes RI, 2020). Dalam kurun waktu kurang dari satu setengah bulan, kasus positif COVID-19 berkembang menjadi 4.241 kasus dengan angka kematian sebanyak 373 orang. Persentase angka kematian di Indonesia tergolong tinggi, per tanggal 12 April tercatat sebesar $8,8 \%$ yang merupakan persentase angka 
kematian tertinggi nomor dua di dunia setelah Italia. Kasus tertinggi berada di wilayah DKI Jakarta sebanyak 2044 kasus disusul Provinsi Jawa Barat sebanyak 450 kasus. Grafik perkembangan kasus terpapar Covid-19 di Indonesia bisa dilihat pada Gambar 2.

\section{PERKEMBANGAN COVID-19}

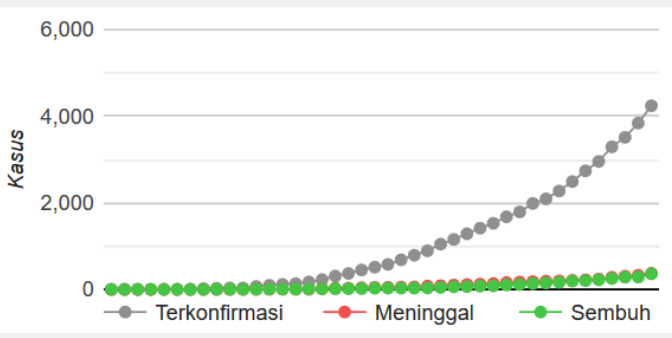

Gambar 2. Grafik Perkembangan Kasus terpapar COVID-19 di Indonesia

Menindaklajuti lonjakan kasus yang terkonfirmasi positif COVID-19, segenap pihak bekerjasama untuk menekan angka kenaikan korban terdampak. Berbagai formula kebijakan dibahas di level pemerintah hingga dibuat himbauan untuk jaga jarak (physical distancing). Himbauan ini dilaksanakan untuk melakukan pembatasan interaksi masyarakat. Instansiinstansi, terutama instansi pemerintah menerapkan program bekerja di rumah (work from home). Kementerian pendidikan juga telah melaksanakan program belajar di rumah (learning from home) semenjak 16 Maret 2020.

Sebagai provinsi dengan kasus positif COVID-19 tertinggi, DKI Jakarta dianggap sebagai wilayah pusat penyebaran COVID-19 di Indonesia. Penyebaran virus tersebut dipengaruhi oleh masih rendahnya tingkat kesadaran masyarakat atas bahaya virus ini. Indikator ini dapat dilihat dengan masih banyak ditemukan masyarakat berkumpul atau tidak mengenakan masker di area publik padahal sedang dalam masa menjalankan kegiatan belajar atau bekerja di rumah. Pemerintah, melalui Menteri Kesehatan RI mencoba kebijakan baru untuk mencegah perluasan penyebaran dengan menetapkan status Pembatasan Sosial Berskala Besar (PSBB) dimulai dari wilayah DKI Jakarta. Keputusan tersebut telah ditetapkan tanggal 7 April 2020 melalui Keputusan Menteri Kesehatan Nomor HK.01.07/Menkes/239/2020. PSBB di DKI Jakarta diberlakukan sejak tanggal 10 April 2020 dengan latar belakang tingginya jumlah kasus dan kematian serta adanya epidemologis di tempat lain. PSBB berikutnya dilaksanakan di wilayah Tangerang melalui Keputusan Menteri Kesehatan
Nomor HK.01.07/Menkes/249/2020. Di luar wilayah-wilayah tersebut juga dapat mengajukan PSBB apabila memenuhi persyaratan yang tertulis di dalam KMK. Pelaksanaan PSBB diantaranya pembatasan fasilitas umum, peliburan tempat kerja, sekolah, kegiatan keagamaan, social budaya dan moda transportasi. Apabila melakukan pelanggaran, akan ditertibkan oleh aparat hingga pemberlakuan hukuman kurungan.

Profesional kesehatan berada di garis depan, bekerja untuk mengendalikan dan mengurangi penyebaran penyakit ini. Kemajuan yang luar biasa cepat telah dibuat dalam penelitian biologis dan biomedis, termasuk mengidentifikasi virus, mengurutkan gen-nya, dan menyelesaikan struktur protein yang meyakinkan (Lu, et al. 2020). Ahli dalam berbagai disiplin ilmu juga merasa terpanggil untuk melakukan kajian lebih dalam mengenai virus tersebut. Kajian dalam bidang Kimia Fisika, juga turut mengambil peran untuk memutuskan rantai penyebaran virus. Salah satu kajian yang menarik untuk dipelajari adalah kajian mengenai inaktivasi virus melalui kinetika disinfeksi.

\section{METODE}

Penulisan ini bersifat kualitatif dengan metode analisis konsep. Metode penulisan yang digunakan adalah metode deskriptif kualitatif dengan pendekatan post-positivistik. Metode ini dilakukan dengan mendiskusikan dan mengevaluasi terkait hasil penelitian ataupun tulisan artikel sebelumnya. Literatur yang digunakan bersumber dari berbagai jurnal internasional, nasional, serta sumber lain yang terakreditasi dan dapat dipertanggungjawabkan

Langkah-langkah dalam penulisan artikel ini adalah 1) Menentukan topik, 2) mengumpulkan bahan sebagai referensi, 3) membuat pendahuluan, 4) menentukan metode; 5) membuat pembahasan; dan 6) menarik kesimpulan kesimpulan (Rizaldi, 2020).

\section{HASIL DAN PEMBAHASAN}

\section{a. Pola Penyebaran Virus}

Jalur infeksius umum untuk penyakit pernapasan seperti influenza, SARS, MERS, dan COVID-19 dimulai dari cairan pernapasan yang sarat dengan virion, yaitu tetesan (berdiameter <1 hingga $2000 \mu \mathrm{m}$ ) dilepaskan oleh orang yang terinfeksi 
melalui batuk, bersin, dan bahkan berpotensi berbicara (Weber, 2008). Ahli medis di Indonesia mengenalkan virion ini dengan istilah droplet. Tetesan ini dengan segera mengalami penguapan dan penyusutan volume. Sebagian besar tetesan dan endapan inti kering pada berbagai objek (misal pada kenop pintu, permukaan meja, uang, pegangan tangan, atau fasilitas publik berupa layar sentuh), mengubahnya menjadi "fomites" yang berpotensi menular. Ilustrasi penyebaran umum penyakit pernafasan melalui fomites, bisa dilihat pada Gambar 3.

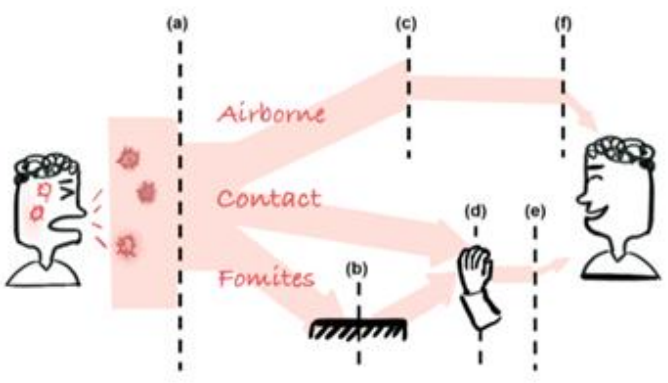

Gambar 3. Grafik Jalur Transmisi Umum Penyakit Pernapasan

(Sumber: Huang, 2020)

Pada gambar di atas menjelaskan proses penyebaran dimulai dengan orang yang terinfeksi melepaskan tetesan cairan pernapasan virion (kiri). Infeksi langsung dengan demikian dapat terjadi melalui penghirupan oleh orang lain dalam jarak dekat (misal 1-2 m), terutama untuk orang banyak di ruang yang relatif tertutup. Infeksi juga dapat terjadi ketika virion yang dilepaskan oleh orang yang terinfeksi tersebar di tangan dan pakaian mereka dan kemudian ditransfer ke orang lain melalui kontak dekat, seperti berjabat tangan. Infeksi fomites tidak langsung dan agak tersembunyi; itu terjadi hanya jika seseorang pertama kali mengambil virion dari benda dan permukaan yang terkontaminasi (misal dengan tangan mereka) dan kemudian memindahkannya ke mulut, hidung, atau mata (Otter, 2016). Oleh karena itu, terdapat banyak peluang untuk membangun penghalang dengan menggunakan pendekatan ilmu fisik dan teknik (garis putus-putus pada Gambar 3) untuk memblokir dan menonaktifkan mayoritas virion yang dilepaskan sebelum mereka mencapai host dan menembus pertahanan biologis dan imunologis terakhir. Beberapa contoh termasuk (a) mengisolasi pasien infeksi atau mengurangi penyebaran tetesan cairan pernapasan mereka, membersihkan dan membersihkan objek dan permukaan, (c) menyaring udara yang berpotensi terkontaminasi, (d) sering mencuci tangan, (e) membangun kebiasaan higenis pribadi yang lebih baik, dan (f) mengenakan alat perlindungan diri (APD).

Memahami struktur dasar virion dan lingkungannya diperlukan untuk merancang strategi inaktivasi, menghilangkan, dan memaksimalkan efektivitas hambatan ini (Gambar 3). Semua penghalang pertahanan ini berkontribusi untuk memblokir sumber virion, memutus jalur penyebaran, dan melindungi host yang rentan. Dibandingkan dengan penyakit menular lain yang diketahui disebabkan oleh coronavirus, COVID-19 dapat menyebar melalui transmisi asimptomatik, yang menyebabkan kesulitan dalam mendeteksi, memantau, dan mencegah penyebarannya. Sebagai penderita COVID-19, seorang asimptom sudah positif tetapi tidak menunjukkan gejala klinis apapun sampai obyek tersebut melakukan tes medis. Hal tersebut menjadi hal yang meresahkan, karena asimptom dapat berperan sebagai seorang carrier (pembawa), yang bisa menularkan virus tanpa disadari.

Penyebaran selain berupa droplet, virus juga dimungkinkan melayang di udara untuk jangka waktu tertentu, sebagai aerosol. Menurut Doremalen (2020), virus SARS-CoV-2 bisa bertahan di permukaan benda lebih dari sehari dan terdeteksi juga di dalam aerosol hingga beberapa jam. Virus hanya hidup di sel inang, tapi dapat bertahan hidup tanpa inang dalam jangka waktu tertentu. Daya tahan virus di luar inang, dipengaruhi oleh suhu, kelembaban, dan pori permukaan. Sehingga, daya tahan virus di permukaan plastik akan lebih lama dibandingkan di permukaan kardus. Penelitian Doremalen telah dirangkum oleh Sidrotun Naim, ahli mikrobiologi dari 
Indonesia Strategic Institute yang dipublikasikan di majalah Tempo seperti pada Gambar 4.

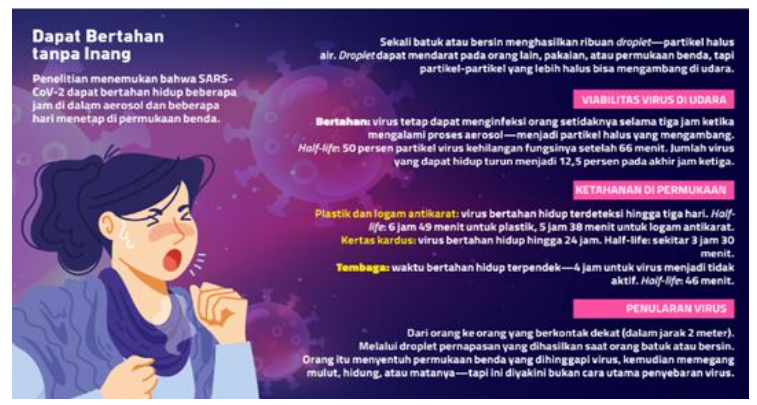

Gambar 4. Daya Tahan Virus Corona di Udara dan di Permukaan Benda

(Sumber : Naim, 2020)

\section{b. Inaktivasi Virus dalam Kajian Kinetika}

Setelah mempelajari pola penyebaran COVID-19, berbagai ahli melakukan penelitian untuk menghambat penyebaran virus tersebut. Diantaranya melakukan inaktivasi virus melalui metode kinetika disinfeksi, yaitu dengan mengatur dosis kumulatif zat terlarut atau produk konsentrasi dan waktu, seperti dalam kinetika desinfeksi. Temuan ini menekankan bahwa kinetika penguapan memainkan peran dalam memodulasi kelangsungan hidup mikroorganisme dalam tetesan (droplet) (Lin \& Marr, 2019). Dalam artikelnya, Lin menyatakan bahwa kelembaban relatif (Relative Humidity/RH) mempengaruhi perkembangan mikroorganisme, termasuk virus. Dalam kehidupan sehari-hari, udara di sekitar diistilahkan dengan udara kering atau lembab, keadaan ini disebut kelembaban udara. Kelembaban udara ini disebabkan oleh kandungan uap air di udara. Semakin banyak uap air di suatu tempat, semakin lembab udara di tempat tersebut. Kelembaban udara ini biasanya dinyatakan dengan kelembaban relatif, yang merupakan perbandingan tekanan parsial air terhadap tekanan uap jenuh pada temperatur tertentu.

Kelembaban Relatif $=\frac{\text { Tekanan Parsial } \mathrm{H}_{2} \mathrm{O}}{\text { Tekanan Uap Jenuh } \mathrm{H}_{2} \mathrm{O}} \times 100 \%$

Flu dapat berkembang baik di daerah sub tropis pada musim dingin dan di musim hujan pada daerah tropis. Penularan patogen yang dikeluarkan oleh orang yang terinfeksi dapat menular melalui media udara. Ketika dilepaskan, virus yang berada di dalam partikel udara bertindak sebagai koloid, yaitu aerosol (zat padat atau zat cair yang terdispersi dalam gas). Virus harus tetap hidup agar bisa menginfeksi orang yang rentan (dalam kondisi tidak fit). Untuk mematikan virus, maka kesehatan reproduksi virus harus dirusak. Dalam penelitian yang dilakukan oleh Lin \& Marr (2019) kinetika disinfeksi menggunakan mekanisme inaktivasi virus yang bergantung pada kelembaban menggunakan model bakteriofag (sebagai model pathogen) dalam aerosol tersuspensi.

$$
\text { Hasil penelitian terhadap }
$$

kemungkinan ketahanan hidup (viabilitas) bakteri dan virus, bahwa efek $\mathrm{RH}$ berpengaruh terhadap viabilitas bakteri dan virus baik dalam aerosol maupun droplet. Viabilitas bakteri tertinggi berbanding lurus dengan $\mathrm{RH}$, viabilitas tertinggi berada di di $\mathrm{RH}$ tinggi dan terendah di $\mathrm{RH}$ rendah. Sedangkan virus memiliki viabilitas yang tinggi pada $\mathrm{RH}$ rendah dan $\mathrm{RH}$ tinggi, sementara pada $\mathrm{RH}$ menengah mengalami kerusakan. Hal tersebut sesuai dengan pengamatan yang dilakukan pada penyakit menular tertentu, seperti influenza, yang insidennya paling tinggi di musim dingin di daerah beriklim sedang, ketika $\mathrm{RH}$ dalam ruangan rendah, dan selama hujan musim di daerah tropis, ketika $\mathrm{RH}$ sangat tinggi (Tamerius, et al. 2011).

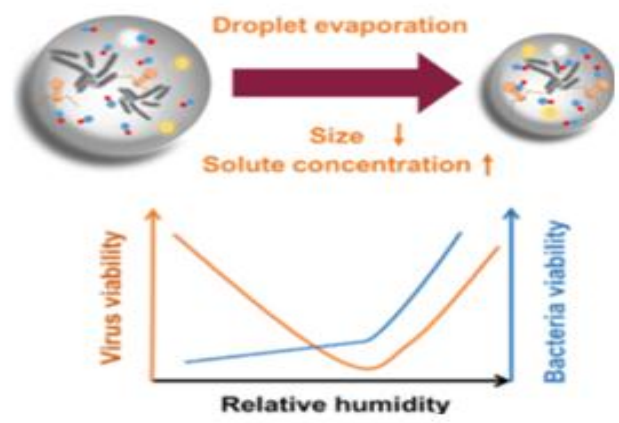

Gambar 5. Viabilitas Virus dan Bakteri terhadap Kelembaban Relatif

Lin \& Marr (2019) juga melakukan eksplorasi kinetika penguapan tetesan dan 
evolusi konsentrasi zat terlarut dalam tetesan penguapan. Kesimpulannya bahwa tekanan osmotik, yang dihasilkan dari peningkatan konsentrasi garam ketika aerosol dan droplet menguap, dapat menyebabkan bakteri terinaktivasi. Sementara, tekanan osmotik dapat menyebabkan penyusutan dan hilangnya aktivitas vaksin dari virus. Peran oksidan seperti ozon, $\mathrm{H}_{2} \mathrm{O}_{2}$, atau radikal hidroksil menonaktifkan virus dengan cara memecah genom dan kapsid. Fenomena proses penguapan tersebut dapat dijelaskan dengan dasar teori kinetik. Dalam larutan molekul-molekul air berada dalam keadaan tarik-menarik satu sama lain, gaya ini membuat molekul air berdekatan pada fase cair. Jika terjadi kenaikan temperatur, molekul-molekul air akan bergerak lebih cepat yang berarti energi kinetiknya meningkat. Molekul air yang mempunyai energi kinetik tinggi mampu melawan gaya tarik molekul lain, mengakibatkan molekul tersebut dapat terlepas dari ikatan molekul lain, dan berubah menjadi fase gas. Akan tetapi, jika molekul tidak memiliki tingkat yang memadai untuk berubah menjadi fase gas, maka ia akan tertarik kembali ke permukaan air. Peristiwa tersebut dapat diterangkan melalui persamaan berikut:

$$
\mathrm{E}_{\mathrm{k}}=\frac{3}{2} \mathrm{NkT} \text { atau } \mathrm{E}_{\mathrm{k}}=\frac{3}{2} \mathrm{nRT}
$$

Keterangan

$$
\begin{array}{lll}
\text { Ek } & : & \text { Energi kinetik translasi rata-rata gas }(\mathrm{J}) \\
\mathrm{k} & : & \text { Tetapan Boltzman }\left(1,38 \times 10^{-23} \mathrm{~J} / \mathrm{K}\right) \\
\mathrm{T} & : \text { Temperatur mutlak gas }(\mathrm{K}) \\
\mathrm{n} & : & \text { Jumlah mol gas } \\
\mathrm{R} & : & \text { Konstanta gas ideal }(8,31 \mathrm{~J} / \mathrm{mol} . \mathrm{K}
\end{array}
$$

\section{c. Inaktivasi Virus dalam Kajian Termodinamika dan Kesetimbangan}

Sebuah studi juga pernah dilakukan oleh Laude (1981) terhadap coronavirus yang juga diketahui menjadi masalah saat itu, yaitu dengan cara inaktivasi termal. Hasil riset menunjukkan bahwa hilangnya daya infeksi virus mengikuti kinetika orde pertama kecuali pada suhu tertinggi (Gambar 6). Ketika virus tidak aktif sesuai dengan reaksi orde pertama, konstanta laju reaksi mengikuti Persamaan Arrhenius:

$$
\mathrm{k}^{\prime}=-\left(\frac{\ln \mathrm{V}_{\mathrm{t}}}{\ln \mathrm{V}_{\mathrm{o}}}\right) \mathrm{t}
$$

\section{Keterangan}

$\mathrm{k}^{\prime} \quad$ : Konstanta laju reaksi

$\mathrm{V}_{\mathrm{t}}$ : Konsentrasi virus yang bertahan hidup

$V_{o}:$ Konsentrasi asli virus menular

t : Waktu

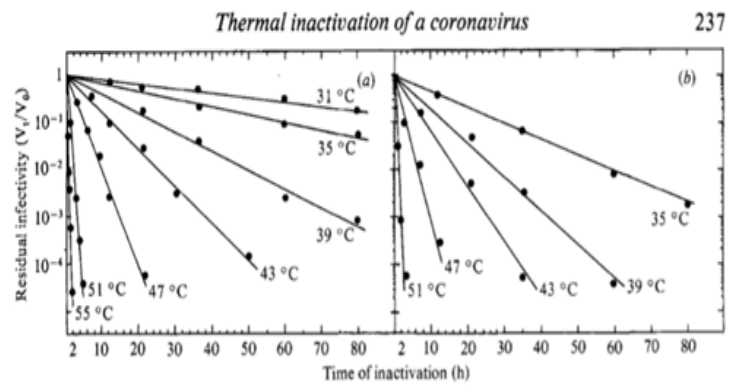

Gambar. 6. Laju Inaktivasi Termal coronavirus pada (a) $\mathrm{pH} 7$ atau (b) $\mathrm{pH} 8$

(Sumber : Laode, 1981)

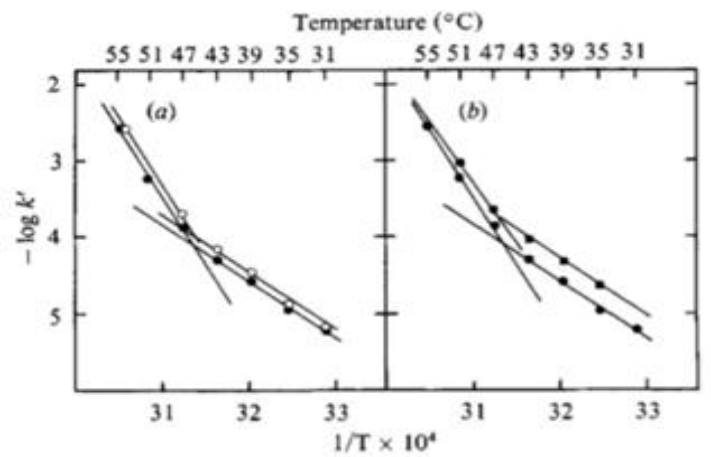

Gambar. 7. Plot Arrhenius untuk Inaktivasi Termal Virus

(Sumber : Laode, 1981)

Gambar 7. di atas menjelaskan terkait logaritma konstanta laju diplot terhadap kebalikan dari temperatur absolut, Nilai k 'berasal dari grafik seperti yang ditunjukkan pada Gambar. 6 (untuk 55 ${ }^{\circ} \mathrm{C}$, nilai k' sesuai dengan komponen inaktivasi cepat). I. strain dipanaskan pada $\mathrm{pH}$ 7; II, strain dipanaskan pada $\mathrm{pH} 8$.

\section{KESIMPULAN}

Berdasarkan pembahasan diketahui bahwa salah satu bentuk pencegahan penyebaran COVID-19 dengan cara inaktivasi virus. Bentuk pencegahan yang dapat dilakukan oleh 
masyarakat tersebut dengan tetap memperhatikan protokol kesehatan seperti menggunakan masker, menjaga jarak, dan mencuci tangan pada air yang mengalir.

\section{DAFTAR PUSTAKA}

Doremalen, N. et al. (2020). Aerosol and surface stability of SARS-CoV-2 as compared with SARS-CoV-1. New England Journal of Medicine, 382(16), 1564-1567.

Huang, H., et al. (2020). COVID-19: A Call for Physical Scientists and Engineers. ACS nano, 14(4), 3747-3754.

\section{Keputusan Menteri Kesehatan Nomor HK.01.07/Menkes/239/2020 tentang Pembatasan Sosial Berskala Besar (PSBB) untuk wilayah DKI Jakarta.}

Keputusan Menteri Kesehatan Nomor HK.01.07/Menkes/249/2020 tentang Pembatasan Sosial Berskala Besar (PSBB) untuk wilayah Kabupaten Tangerang, Kota Tangerang, Tangerang Selatan.

Laude, H. (1981). Thermal inactivation studies of a coronavirus, transmissible gastroenteritis virus. Journal of General Virology, 56(2), 235-240.

Lin, K., \& Marr, L. C. (2019). Humiditydependent decay of viruses, but not bacteria, in aerosols and droplets follows disinfection kinetics. Environmental Science \& Technology, 54(2), 1024-1032.

Lu, R. et al. (2020). Genomic characterisation and epidemiology of 2019 novel coronavirus: implications for virus origins and receptor binding. The Lancet, 395(10224), 565-574.

Naim, S. (2020). Aktivitas Hidup COVID-19. [Online]. Available: https://majalah. tempo.co/read/ilmu-dan teknologi/16 0086/mengapa-virus-corona-bisa-ber tahan-hidup-di-aerosol-dan-permukaan- benda\&user=register?hidden=login. diakse s (Accesed: 11-04-2020).

Otter, J. A., et al. (2016). Transmission of SARS and MERS coronaviruses and influenza virus in healthcare settings: the possible role of dry surface contamination. Journal of Hospital Infection, 92(3), 235-250.

Rizaldi, D. R., Nurhayati, E., \& Fatimah, Z. (2020). The Correlation of Digital Literation and STEM Integration to Improve Indonesian Students' Skills in 21st Century. International Journal of Asian Education, 1(2), 73-80.

Roylab State. (2020). Coronavirus Pandemic: Real Time Counter, World Map. [Online]. Available: http"//https://www.youtube. com/channel/UCDGiCfCZIV5phsoGiPwI cyQ. [Accessed: 12-Apr-2020].

Tamerius, J. et al. (2011). Global influenza seasonality: reconciling patterns across temperate and tropical regions. Environmental health perspectives, 119(4), 439-445.

Weber, T. P., \& Stilianakis, N. I. (2008). Inactivation of influenza A viruses in the environment and modes of transmission: a critical review. Journal of infection, 57(5), 361-373.

WHOa. (2020). Pneumonia of unknown cause China. [Online]. Available: http:// www.who.int/csr/don/05-january-2020pneumonia-of-unkown-cause-china/en/. [Accessed: 09-Apr-2020].

WHOb. (2020). WHO Director-General's Opening Remarks at the Media Briefing on Covid-19-11 March 2020. [Online]. Available:https://www.who.int/dg/speech es/detail/who-director-general-s-openingremarks-at-themedia-briefing-on-covid19---11-march-2020 (Accessed 2020-0409). 